\title{
The Potentiality of Human Umbilical Cord Isolated Mesenchymal Stem/ Stromal Cells for Cardiomyocyte Generation [Corrigendum]
}

Abou-ElNaga A, El-Chennawi F, Ibrahim kamel S, Mutawa G. Stem Cells Cloning. 2020; 13:91-101.

On page 99, Acknowledgment section, "We thank "MERC" of Mansoura Faculty of Medicine for their support. We appreciate the excellent English editorial assistance of Nermine A. Gomaa, associate professor of English literature at Horus University" should have been
"This work was done in Mansoura Research Center for Cord Stem Cells (MARC-CSC) Faculty of Medicine, Mansoura University. We appreciate the excellent English editorial assistance of Nermine A. Gomaa, associate professor of English literature at Horus University".

The authors apologize for this error.

\section{Publish your work in this journal}

Stem Cells and Cloning: Advances and Applications is an international, peer-reviewed, open access journal. Areas of interest in established and emerging concepts in stem cell research include: Embryonic cell stems; Adult stem cells; Blastocysts; Cordblood stem cells; Stem cell transformation and culture; Therapeutic cloning; Umbilical cord blood and bone marrow cells; Laboratory, animal and human therapeutic studies; Philosophical and ethical issues related to stem cell research. This journal is indexed on CAS. The manuscript management system is completely online and includes a very quick and fair peer-review system, which is all easy to use. Visit http://www.dovepress.com/testimonials.php to read real quotes from published authors.

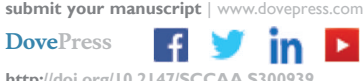

http://doi.org// $0.2147 /$ SCCAA.S300939
Stem Cells and Cloning: Advances and Applications 2021:14 I

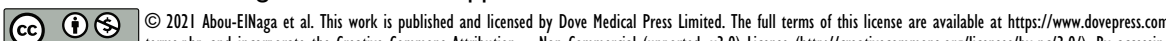
(c) the work you hereby accept the Terms. Non-commercial uses of the work are permitted without any further permission from Dove Medical
For permisision for commercial use of this work, please see paragraphs 4.2 and 5 of our Terms (https://www dovepress com/terms php). 